ARTÍCULO

\title{
UNA NUEVA FORMA DE APOSTOLADO \\ IGLESIA CATÓLICA, SOCIEDAD Y AUTORIDADES LOCALES EN LA DIÓCESIS \\ DE CAMPECHE, 1922-1926
}

\section{A NEW FORM OF APOSTOLATE \\ CATHOLIC CHURCH, SOCIETY AND LOCAL AUTHORITIES IN THE DIOCESE \\ OF CAMPECHE, 1922-1926}

\section{Sergio Rosas Salas}

Benemérita Universidad Autónoma de Puebla

Instituto de Ciencias Sociales y Humanidades "Alfonso Vélez Pliego"

sergiofrosas@yahoo.com.mx

\section{Resumen}

El artículo tiene como objetivo reconstruir y analizar el proyecto de fortalecimiento eclesial emprendido en la diócesis de Campeche entre 1922 y 1925, así como los conflictos con las autoridades civiles que llevaron al enfrentamiento entre Iglesia y Estado en 1926. A partir de una revisión de la correspondencia diocesana, el artículo argumenta que el obispo Francisco González Arias propició desde su llegada en 1922 y hasta su exilio en 1926 varios mecanismos de renovación diocesana, como la construcción material de templos, la organización de los seglares y el fomento al culto religioso a través de iniciativas como las consagraciones generales. Se concluye que el éxito de estas medidas fue una causa de los constantes enfrentamientos con las autoridades locales y, por tanto, de la expulsión de buena parte del clero diocesano en 1926.

Palabras clave: Iglesia católica; diócesis de Campeche; conflicto religioso; Quintana Roo.

\begin{abstract}
This article aims to recreate and analyze the strengthening ecclesiastical project undertaken by the Campeche Diocese between 1922 and 1925, as well as its disputes with civil authorities which eventually led to the conflict between Church and State in 1926. Based on a review of diocesan correspondence, the article argues that Bishop Francisco González Arias did sponsor diverse activities as temples building, secular organizing, and religious cult encouragement through initiatives such as the general consecrations since his arrival in 1922 up until his eviction in 1926.
\end{abstract}

Keywords: Catholic Church; diocese of Campeche; religious conflict; Quintana Roo.

Información del artículo

Recibido: 29 de septiembre de 2019.

Aceptado: 11 de diciembre de 2019.

DOI: 10.22201/iih.24485004e.2020.59.70959 


\section{Introducción}

Este artículo analiza el proyecto de fortalecimiento eclesial emprendido en la diócesis de Campeche entre 1922 y 1925, mediante la reconstrucción de las estrategias y mecanismos de las autoridades diocesanas para ampliar la presencia eclesial en la ciudad episcopal y las parroquias del obispado, así como los conflictos que llevaron a un creciente enfrentamiento del clero con las autoridades civiles entre 1925 y 1926. El fortalecimiento del culto, los templos y las estructuras eclesiásticas fueron impulsados por el obispo Francisco González Arias, quien a través de diversos mecanismos pastorales, organizativos y simbólicos buscó mostrar el vigor de la Iglesia en su diócesis. En una sociedad acostumbrada a una escasa presencia de la jerarquía eclesiástica y a un catolicismo centrado en las propias comunidades, las iniciativas clericales transformaron la relación de los seglares con el clero y animaron un creciente choque con los ayuntamientos. ${ }^{1} \mathrm{~A}$ la par que se fortalecía el culto, las autoridades locales consideraron que algunos elementos bajo el control del clero, como el registro de las estadísticas de la población, eran parte de sus atribuciones, y en consecuencia no se debía permitir el dominio exclusivo de la Iglesia sobre ellas. Al reconstruir estos procesos, las líneas que siguen analizan los mecanismos de fortalecimiento de la Iglesia, el clero y el catolicismo diocesano en la década de 1920 y reconstruyen los enfrentamientos que desembocaron en 1926 en el exilio del clero, desde una perspectiva regional.

Esta preocupación no es inédita. En los últimos años los historiadores han prestado atención a los procesos de renovación eclesiástica durante la Revolución, y han mostrado que durante el régimen de Álvaro Obregón se vivió una creciente presencia de la Iglesia en la sociedad. ${ }^{2}$ Asimismo, la

${ }^{1}$ Armando José Rosado Cel, Francisco Plancarte y Navarrete. El obispo arqueólogo (Campeche: Archivo Histórico de la Diócesis de Campeche, 2016), 53-54; Ángel Omar May González, Conflicto religioso en Campeche, 1925-1929 (Campeche: Gobierno del estado de Campeche, PACмYс, 2007); sobre el catolicismo peninsular durante el siglo XIX, Terry Rugeley, De milagros y sabios: religión y culturas populares en el sureste de México, 1800-1876 (Mérida: Ediciones de la Universidad Autónoma de Yucatán, 2012).

${ }^{2}$ Para María Eugenia García Ugarte, "Etapa de intransigencias: disputa por el espacio social”. En Estado, Iglesia y sociedad en México. Siglo XIX, coord. de Álvaro Matute (México: Universidad Nacional Autónoma de México/Miguel Ángel Porrúa, 1995), en el obregonismo se vivió una disputa por el "espacio social”; para María Gabriela Aguirre Cristiani, ¿Una historia compartida? Revolución mexicana y catolicismo social, 1914-1924 (México: Instituto Mexicano de Doctrina Social Cristiana/Instituto Tecnológico Autónomo de México/ 
literatura ha demostrado que las variadas posturas locales ante el enfrentamiento religioso de 1926 respondían a las diversas tradiciones locales y al impacto del catolicismo social en cada diócesis. La historia regional ha sido fundamental para ampliar nuestro conocimiento de esta problemática. Para citar dos ejemplos recientes, Franco Savarino demostró que la ausencia de un conflicto armado en Chihuahua hasta la década de 1930 se debió a las características del catolicismo local y a la pastoral del mitrado Antonio Guízar y Valencia, mientras que en Totatiche y el cañón de Bolaños, en Jalisco, la base de la enorme presencia eclesial fue la formación de los lai$\cos ^{3}$ El presente trabajo acerca de Campeche pretende contribuir a estas nuevas miradas regionales sobre la Cristiada, así como subrayar algunos elementos que permitan situar el caso estatal en el marco nacional. ${ }^{4}$ En ese sentido, el estudio de Campeche, marcado por una fuerte presencia indígena y una clerecía débil, muestra una notable diferencia con los casos de aquella región del país, como Tabasco y Yucatán, donde los gobernadores

Universidad Autónoma Metropolitana, 2008), Obregón inició una política pragmática de conciliación de intereses.

${ }^{3}$ Franco Savarino, El conflicto religioso en Chihuahua 1918-1937 (Chihuahua: El Colegio de Chihuahua/Universidad Autónoma de Ciudad Juárez, 2018); y Eduardo Camacho Mercado, Frente al hambre y al obús: Iglesia y feligresía de Totatiche y el Cañón de Bolaños, 1876-1926 (Guadalajara: Departamento de Estudios Históricos de la Arquidiócesis de Guadalajara/ Universidad de Guadalajara, Centro Universitario de los Lagos, 2014). Son importantes también los trabajos sobre Chiapas, Yucatán y Oaxaca de Miguel Lisbona Guillén, Persecución religiosa en Chiapas (1910-1940): Iglesia, Estado y feligresía en el periodo revolucionario (México: Universidad Nacional Autónoma de México, Instituto de Investigaciones Antropológicas, Programa de Investigaciones Multidisciplinarias sobre Mesoamérica y el Sureste, 2008); "Iglesia católica y Estado en la posrevolución chiapaneca. Desencuentros y conflictos, 19171940”. En México católico. Proyectos y trayectorias eclesiales en México. Siglos XIX y XX, coord. de Marta Eugenia García Ugarte, Pablo Serrano Álvarez y Matthew Butler (Pachuca: Universidad Intercultural del Estado de Hidalgo/El Colegio del Estado de Hidalgo/Consejo Estatal para la Cultura y las Artes de Hidalgo, 2016); Franco Savarino, Pueblos y nacionalismo: del régimen oligárquico a la sociedad de masas en Yucatán, 1894-1925 (México: Instituto Nacional de Estudios Históricos de la Revolución Mexicana, 1997); "La Iglesia católica y el Estado durante la Revolución. Yucatán, 1910-1923”. En México católico. Proyectos y trayectorias eclesiales en México. Siglos XIX y XX, coord. de Marta Eugenia García Ugarte, Pablo Serrano Álvarez y Matthew Butler (Pachuca: Universidad Intercultural del Estado de Hidalgo/El Colegio del Estado de Hidalgo/Consejo Estatal para la Cultura y las Artes de Hidalgo, 2016); y Jean Meyer, El conflicto religioso en Oaxaca, 1926-1929 (México: Centro de Investigación y Docencia Económicas, Documentos de Trabajo, 2005), respectivamente.

${ }^{4}$ La escasa atención pastoral en Campeche fue resultado, en buena medida, de la poca disponibilidad de sacerdotes y de la alta población indígena de lengua maya. Cfr. Massimo de Giuseppe, Messico 1900-1930. Stato, Chiesa e popoli indigeni (Brescia: Morcelliana, 2007). 
Tomás Garrido Canabal y Salvador Alvarado emprendieron una ardua campaña anticlerical incluso desde la década de 1910, la cual encontró su expresión más radical en los Camisas Rojas tabasqueños en la década de $1930 .^{5}$ Mientras en estos estados del sureste se vivió un abierto enfrentamiento que alcanzó tintes de violencia, y en Jalisco y Michoacán la población reaccionó a la clausura de los templos con un levantamiento armado, en Campeche se prefirió la negociación y el exilio antes que el enfrentamiento directo. Así, este artículo contribuye a matizar la experiencia nacional y profundiza en un caso que nos ayuda a conocer mejor las diversas experiencias regionales del conflicto religioso. ${ }^{6}$

Hasta ahora, sólo May González ha profundizado en el estudio de la creciente tensión entre Iglesia y Estado en Campeche durante la década de 1920, si bien su investigación enfatizó los entendimientos entre ambos hasta el fin de la Cristiada en 1929. ${ }^{7}$ En suma, la historiografía ha llamado la atención respecto a la necesidad de estudiar los años previos al conflicto religioso de 1926, y ha insistido en lo fecundo de las miradas locales para comprender estos procesos. ${ }^{8} \mathrm{El}$ consenso de los estudiosos es que el periodo que va de 1921 a 1924 constituyó un momento de fortalecimiento de la Iglesia en México, marcado por los trabajos de la jerarquía eclesiástica para

${ }^{5}$ Sobre Yucatán, véase Francisco J. Paoli y Enrique Montalvo, El socialismo olvidado de Yucatán (México: Siglo XXI, 1977); y sobre Tabasco, véase Carlos Martínez Assad, El laboratorio de la revolución: el Tabasco garridista (México: Siglo XXI, 1979).

${ }^{6}$ El impacto de la suspensión del culto y la respuesta del clero y la población católica mexicana han sido temáticas ampliamente analizadas en archivos romanos y nacionales en Stephen J. C. Andes, The Vatican and Catholic Activism in Mexico and Chile. The Politics of Transnational Catholicism, 1920-1940 (Oxford: Oxford University Press, 2014); y Paolo Valvo, Pio XI e la Cristiada. Fede, guerra e diplomazia in Messico (1926-1929) (Brescia: Morcelliana, 2016).

${ }^{7}$ Cfr. May González, Conflicto religioso en Campeche..., 2007.

${ }^{8}$ Además de Jean Meyer, La Cristiada, 3 v. (México: Siglo XXI, 2006), véanse las miradas regionales de Matthew Butler, Devoción y disidencia: religión popular, identidad política y rebelión cristera en Michoacán, 1927-1929 (Zamora: El Colegio de Michoacán/Fideicomiso Felipe Teixidor y Monserrat Alfau de Teixidor, 2013); y Enrique Guerra Manzo, Del fuego sagrado a la acción cívica: los católicos frente al Estado en Michoacán (1920-1940) (Zamora: El Colegio de Michoacán/Universidad Autónoma Metropolitana/Ítaca, 2015); además de la perspectiva de Juan González Morfín, La guerra de los cristeros. Hitos y mitos (Los Mochis: Panorama, 2017), así como los trabajos coordinados por Yves Bernardo Roger Solís Nicot, "Catolicismo triunfante o crisis del catolicismo social y político: el Congreso Eucarístico de 1924”, en Política y religión en la ciudad de México, siglos XIX y XX, coord. de Franco Savarino, Berenise Bravo Rubio y Andrea Mutolo (México: Instituto Mexicano de Doctrina Social Cristiana, 2018). 
afianzar su liderazgo social y por los afanes de un laicado movilizado gracias al catolicismo social. Del mismo modo, han mostrado que a partir de 1925 la renovación y el fortalecimiento de la Iglesia dieron paso a una disputa - muchas veces simbólica- que desembocó en el conflicto armado un año más tarde.

A la luz de estos avances vale la pena insistir en que este artículo tiene como objetivo analizar las estrategias del clero de la diócesis de Campeche para fortalecer la presencia eclesial en la entidad entre 1922 y 1925, así como la reacción y la respuesta de las autoridades civiles al creciente liderazgo simbólico y social del clero y de la Iglesia católica entre 1925 y 1926. Dos grandes cambios enmarcan el periodo analizado: la llegada del obispo Francisco González y Arias en agosto de 1922 y el exilio de una buena parte del clero diocesano a lo largo de 1926. En realidad estas líneas cuentan la historia de muy pocos clérigos. Cuando el 22 de agosto de 1922 Francisco González Arias tomó posesión del obispado encontró una diócesis de gran extensión territorial - cubría el estado de Campeche y la mitad sur del actual estado de Quintana Roo- pero de escaso personal: apenas contaba con 10 sacerdotes, 8 mexicanos y dos españoles. ${ }^{9}$ Ya el primer obispo de la diócesis, Francisco Plancarte y Navarrete, había enfrentado la escasez de clero. Al iniciar el siglo xx, Plancarte contaba con 15 presbíteros, entre quienes estaban algunos clérigos españoles que él mismo ordenó. Preocupado por la situación, el mitrado Francisco Mendoza y Herrera fundó el seminario en 1905; a él llegaron alumnos de la diócesis de Zamora y cinco jóvenes peninsulares provenientes de Burgos. ${ }^{10}$ La combinación de

${ }^{9}$ Luis H. Maldonado, "Circular número 1 de Francisco, obispo de Campeche”, Archivo Histórico de la Diócesis de Campeche "Monseñor Francisco Plancarte y Navarrete" (en adelante AHDC), Sección Gobierno y Administración, Serie Correspondencia, expediente 1653, “Circulares del Gobierno Eclesiástico de la Diócesis de Campeche, 1922-1923”, así como Oficio del secretario de Cámara y Gobierno del obispado al inspector general de policía, Campeche, 3 de abril de 1925, AHDC, expediente 1503, Correspondencia con el gobierno civil, 1922-1926. La diócesis de Campeche se fundó en 1895, como parte de las fundaciones diocesanas creadas durante el porfiriato. Cfr. José Bravo Ugarte, Diócesis y obispos de la Iglesia mexicana, 1519-1965 (México: Jus 1965); y José Miguel Romero de Solís, El aguijón del espíritu: historia contemporánea de la Iglesia en México, 1892-1992 (México: Instituto Mexicano de Doctrina Social Cristiana/El Colegio de Michoacán/Archivo Histórico del Municipio de Colima/Universidad de Colima, 2006), 69. Además de Campeche, se fundaron las diócesis de Chihuahua, Cuernavaca, Saltillo, Tehuantepec y Aguascalientes.

${ }^{10}$ Luis A. Osorio Díaz, Tesoros de un archivo. Archivo Histórico de la Diócesis de Campeche (San Francisco de Campeche: Gobierno del Estado de Campeche, 2015), 69-70; Rosado Cel, Francisco Plancarte y Navarrete..., 57-75. 
clérigos mexicanos y españoles permaneció hasta el periodo estudiado; ambos grupos contribuyeron a reconstruir una endeble infraestructura eclesiástica que permitió fortalecer, acaso por primera vez, la relación entre el clero y los seglares en las parroquias de la diócesis.

En conjunto, este artículo busca demostrar que durante este periodo el obispo González y su clero promovieron la presencia organizativa, simbólica y cultual de la Iglesia y del catolicismo en el obispado de Campeche a través de la construcción de templos, el fomento y cuidado del culto y, en general, una pastoral diocesana que insistió en la práctica sacramental, en la formación de los laicos, en la mejora de los espacios dedicados al culto y en el cuidado de la jurisdicción eclesiástica. En este contexto, la promoción del Congreso Eucarístico Nacional de 1924 en la diócesis suscitó una mayor actividad del clero en las parroquias. En última instancia, el ritmo de consagraciones que trajo a la diócesis fue uno de los factores para llegar a un enfrentamiento cada vez mayor del clero con los presidentes municipales. Así, los conflictos de los párrocos y el obispo con las autoridades locales, ya presentes en 1922, llevaron a una polarización social que se profundizó en 1925 y terminó con la salida del clero en 1926. En suma, durante el periodo estudiado encontramos en Campeche un fortalecimiento de las estructuras eclesiales de la diócesis, del culto y de la presencia material y simbólica de la Iglesia gracias al esfuerzo del obispo y el clero diocesano. Su éxito al organizar a los laicos y al incrementar el culto llevó a un constante enfrentamiento con las autoridades locales que a partir de 1925 intentaron limitar la influencia eclesial en la sociedad. Así pues, el fortalecimiento de la presencia y la organización eclesial en la década de 1920 produjo, paradójicamente, el fracaso del proyecto de renovación de la Iglesia católica en 1926.

Presencia material, organización diocesana y resistencia local

Desde su llegada a Campeche, el obispo Francisco González Arias impulsó el liderazgo del clero en la ciudad episcopal y en las distintas parroquias de la diócesis. Para conseguirlo, entre 1922 y 1925 el mitrado y el clero de Campeche echaron mano de tres elementos: la mejora material de los templos, el impulso a las asociaciones - algunas ya existentes-y el fomento de la prensa católica. El proceso retomó la experiencia previa de fortalecimiento de las estructuras eclesiásticas visible en los afanes de los anteriores mitrados, la cual se complementó con la propia experiencia del obispo: además de 
la fundación del seminario en 1905, los mitrados impulsaron la fundación de algunas asociaciones de oración. ${ }^{11}$ Asimismo, hay que tener presentes los antecedentes del obispo. González nació en Cotija, Michoacán, en 1874; tras formarse en el seminario de Zamora fue párroco del templo de La Purísima y canónigo en aquella ciudad en los años en que el mitrado José Othón Núñez y Zárate desarrolló un amplio proyecto de fortalecimiento eclesial a través de la organización de los seglares, quienes desde la parroquia, debían impulsar el catolicismo social. ${ }^{12}$ Con base en esta experiencia, el ordinario impulsó el liderazgo local del clero y en general la organización de los católicos.

Como ya se ha señalado, un primer elemento de estas medidas diocesanas fue la (re)construcción material de los templos. Se trató de una iniciativa compartida por los párrocos y visible en los diversos puntos de la diócesis. En conjunto, el interés constructivo buscó subrayar la presencia de la Iglesia católica en las comunidades y el liderazgo del clero en la sociedad a través de los inmuebles religiosos. El interés en la construcción podía presentarse como el afán de un párroco por reconstruir un templo dañado o bien como el interés de la comunidad y de su cura por fundar un nuevo templo o capilla. Esta experiencia constructiva se manifestó en la ciudad episcopal y en pueblos tan distantes entre sí como Payo Obispo - hoy Chetumal-, Cozumel, Ciudad del Carmen y Calkiní.

En noviembre de 1922 encontramos las primeras iniciativas en este sentido. El 3 de noviembre de aquel año, el párroco de Payo Obispo, Francisco Palau, informó al obispo que estaba "en los preparativos para levantar el templo" de aquella población, el cual se había perdido por los efectos de un ciclón y porque "lo derribaron unas partidas de jefes y oficiales revolucionarios”. El cura señaló que quería erigir el nuevo edificio de ladrillos, pues así podría diferenciarse de "todas las construcciones" de la población, levantadas con madera. ${ }^{13}$ La obra avanzó con dificultades: el 2 de julio de

${ }^{11}$ Osorio Díaz, Tesoros de un archivo..., 52.

${ }^{12}$ Sobre la biografía de González y Arias, véase José Ignacio Dávila Garibi, "Serie cronológico-biográfica de los ilustrísimos mitrados mexicanos consagrados durante un siglo, de marzo 6 de 1831 a marzo 6 de 1931 (5a. y última parte)”, en Boletín Eclesiástico. Órgano Oficial de la Arquidiócesis de Guadalajara (Guadalajara: Arquidiócesis de Guadalajara, año 7, n. 5, 2014), 52. Sobre la diócesis de Zamora y sus proyectos sociales, véase Miguel Hernández Madrid, ed., Documentos de pastoral cívica y social de la Iglesia católica en la diócesis de Zamora, Michoacán, 1930-1970 (Zamora: El Colegio de Michoacán, 2014).

${ }^{13}$ Carta de Francisco Palau al obispo Francisco González, Payo Obispo, 3 de noviembre de 1922, AHDC, Sección Gobierno y Administración, Serie Correspondencia, expediente 1457-A, "Expedientes, cartas, cuentas y documentos". 
1923 Palau pidió permiso oficial para levantar el templo; un año más tarde apuntó que a pesar de las complicaciones reiniciaría la labor de "edificar la Yglesia, pero no pronto, [pues] la población ha quedado muy pobre y apenas está regresando la gente" después de unos ataques armados a la población. Las obras iniciaron formalmente en noviembre de $1924 .{ }^{14} \mathrm{El}$ afán constructor de Palau no se limitó a Payo Obispo; el 21 de octubre de 1923 pidió permiso para edificar un templo en Puerto Morelos: el cura confesó que una parte de la población se oponía, pero también que contaba con el apoyo de varios habitantes; señaló que esperaba poder levantar un "pequeño oratorio", pues en la zona oriental del obispado los templos eran casi inexistentes. ${ }^{15}$

Una de las iniciativas de construcción más exitosas fue la del cura de Calkiní, Miguel A. Peña, quien el 16 de abril de 1924 pidió al obispo que le permitiera bendecir "el nuevo oratorio del suburbio de San Ignacio Kilakán”, en su propia cabecera, lo que se realizó en abril de 1924. Al año siguiente ahí se celebraron las fiestas locales, con "cuatro o cinco misas dedicadas en honor de su santo patrono". ${ }^{16}$ En diciembre, Peña pidió al vicario general Luis H. Maldonado su apoyo para reparar el templo de Dzitbalché, prácticamente en ruinas y sin atrio, ya que éste había sido demolido por el ayuntamiento en enero de $1923 .{ }^{17}$ Como Palau, Peña lamentó no recibir apoyo de la población local; esto le impedía iniciar pronto las reparaciones. Donde sí se pudieron cumplir con más rapidez fue en Champotón; ahí el cura Aniceto Corcuera señaló que había blanqueado la Iglesia, y gracias a ello la podía utilizar para explicar el catecismo. ${ }^{18}$ Meses más

${ }^{14}$ Cartas de Francisco Palau a Luis H. Maldonado, Payo Obispo, 2 de julio de 1923, 1 de julio de 1924 y 18 de noviembre de 1924. La primera carta, en AHDC, expediente 1457, "Expedientes, cartas, cuentas y documentos". Las dos restantes, en AHDC, expediente 1458A. Diversas cartas y documentos varios. Año de 1924.

${ }^{15}$ Carta de Francisco Palau a Luis H. Maldonado, Cozumel, 21 de octubre de 1923, AHDC, expediente 1457, "Expedientes, cartas, cuentas y documentos".

${ }^{16}$ Carta de Miguel A. Peña al vicario general presbítero D. Francisco García, Calkiní, 25 de marzo de 1924, AHDC, expediente 1458-A, "Legajo 1. Diversas cartas documentos varios. Año de 1824".

${ }^{17}$ Carta de Miguel A. Peña al obispo Francisco González, Calkiní, 16 de abril de 1923, AHDC, expediente 1457-A, "Expedientes, cartas, cuentas y documentos"; y Carta de Miguel A. Peña a Luis H. Maldonado, Calkiní, 3 de diciembre de 1923, AHDC, expediente 1457, “Expedientes, cartas, cuentas y documentos”. Véase también Carta de Miguel A. Peña a Luis Higinio Maldonado, Campeche, 30 de enero de 1923, ADHC, expediente 1457, "Expedientes, cartas, cuentas y documentos".

${ }^{18}$ Carta de Aniceto Corcuera a Luis H. Maldonado, Champotón, 4 de diciembre de 1923, AHDC, expediente 1457-A, "Expedientes, cartas, cuentas y documentos". 
tarde, en septiembre de 1924, Corcuera señaló que tenía cien pesos para invertir en el templo de Hool, además de que aportaría 50 pesos de su peculio para levantar una "iglesita" en Pich. ${ }^{19}$ En Ciudad del Carmen, Faustino Rebolledo atendió la reconstrucción de la parroquia. En junio de 1924 el cura señaló que la iglesia sería bendecida a fines de mes, pues la mayor parte de la obra se hallaba concluida, a pesar de que faltaba pintar el interior y el exterior del templo. ${ }^{20}$ En noviembre de aquel año Rebolledo bendijo la iglesia de Atasta, la cual se había "reconstruido y engrandecido, pues ya era pequeña”, y supervisó las obras de la capilla de Sabancuy, que se estaba mejorando, pues "estaba en muy mal estado". ${ }^{21}$

El interés constructivo permite observar que el proyecto católico no recibió un apoyo unánime de parte de la población. Mientras algunos seglares aprovechaban los templos para el catecismo y para las fiestas patronales, en lugares como Payo Obispo no parece haber habido mayor cooperación de parte de los fieles. Desde luego esto muestra los límites de la presencia eclesial buscada por la diócesis, así como los grupos sociales que apoyaron el proyecto. De hecho, la confrontación con las autoridades civiles y con otros grupos sociales no se hizo esperar. En 1923 el ayuntamiento de Dzitbalché derribó el atrio de la iglesia e intentó "abrir una calle por el lado del Norte" para separar la casa cural del templo. ${ }^{22}$ En septiembre, los habitantes de Pomuch, en Hecelchakán, denunciaron que "el jefe del Partido Socialista" en el pueblo ponía "dificultades [...] para evitar que se lleven a cabo las reparaciones de los desperfectos que una corriente eléctrica causó al templo católico" desde agosto de 1922. ${ }^{23}$ En marzo de 1923, un “americano 'Protestante' " predicó en Tenabó “contra la Yglesia”, postulando que "sería mejor que se demoliera la Santa Iglesia para que desaparezca de

${ }^{19}$ Carta de Aniceto Corcuera a Luis H. Maldonado, Palizada, 6 de septiembre de 1924, AHDC, expediente 1458, "Expedientes, cartas, cuentas y documentos".

${ }^{20}$ Cartas de Faustino Rebolledo a Luis H. Maldonado, Ciudad del Carmen, 24 de mayo, 4 de junio y 12 de junio de 1924, AHDC, expediente 1458, "Expedientes, cartas, cuentas y documentos".

${ }^{21}$ Carta de Faustino Rebolledo a Luis H. Maldonado, Ciudad del Carmen, 7 de noviembre de 1924, AHDC, expediente 1458, "Expedientes, cartas, cuentas y documentos".

${ }^{22}$ Carta de Miguel A. Peña a Luis H. Maldonado, Calkiní, 7 de mayo de 1923, AHDc, expediente 1457-A, "Expediente, cartas, cuentas y documentos".

${ }^{23}$ Carta de Lorenzo García Ortega a Francisco González y Arias, Hecelchakán, 26 de septiembre de 1923, AHDC, expediente 1457-A, "Expedientes, cartas, cuentas y documentos"; y Carta de Miguel A. Peña a Luis H. Maldonado, Calkiní, 7 de mayo de 1923, AHDc, expediente 1457-A, "Expediente, cartas, cuentas y documentos". 
una vez en esta población la Religión”. ${ }^{24}$ Como se ve, el rechazo a la presencia física de la Iglesia católica en los pueblos de la diócesis no sólo provenía de las autoridades, sino de diversos actores colectivos, aquí etiquetados como socialistas y protestantes. Hay que tener presente que el proceso de construcción de templos en la diócesis ocurrió en un contexto de formación y consolidación en Campeche de un régimen socialista, ya fuera discursivamente radical, como el del gobernador Ramón Félix Flores, o bien moderado y reformista, como el de Ángel Castillo Lanz. ${ }^{25}$

Como se puede ver por los ejemplos anteriores, entre 1922 y 1924 se promovió la construcción de templos y parroquias campechanas gracias al impulso del clero, a pesar de que hay indicios que apuntan al rechazo de las autoridades locales y de algunos grupos de habitantes. Los afanes de erigir templos no se limitaron a las cabeceras; de hecho, en Payo Obispo, Calkiní y Ciudad del Carmen - por mencionar sólo los casos citados- había un amplio interés de los curas por erigir templos en barrios y comunidades alejadas de la parroquia. Hay dos factores que permiten comprender esta amplia labor de construcción: el clima de paz en el estado durante el régimen de Álvaro Obregón, y sostenido por el régimen moderado de Castillo Lanz, y el interés del clero diocesano por hacer evidente la presencia del clero en la sociedad. Así, tan sólo en 1922 se podían contabilizar 51 templos católicos en la diócesis: 48 en el territorio de Campeche y 3 en Quintana Roo. ${ }^{26}$ En suma, es plausible sugerir que la fiebre constructiva del clero era una respuesta a la incipiente pluralidad religiosa y al impulso del socialismo en la entidad. Era un reclamo de presencia pública en una sociedad marcada por la convivencia con posturas no católicas y con una abierta militancia contra el liderazgo de la Iglesia católica y del clero en las comunidades.

${ }^{24}$ Carta de Bernabé Muñoz al Presbítero Lorenzo García Ortega, Tenabó, 20 de marzo de 1923, AHDC, expediente 1457, "Expedientes, cartas, cuentas y documentos".

25 Ángel Omar May González, Los primeros años de la posrevolución en Campeche (19211929) (México: Instituto de Investigaciones Dr. José María Luis Mora, 2013); José A. Abud Flores, Después de la Revolución: los caciques y el nuevo Estado (Campeche, 1923-1943) (México: Universidad Autónoma Metropolitana, 2012). Es importante señalar que este régimen no emprendió una campaña militantemente anticlerical como sí ocurrió en los vecinos estados de Tabasco y Yucatán.

${ }^{26}$ Oficio del gobernador constitucional del estado de Campeche al subsecretario de gobernación, Campeche, 15 de diciembre de 1922, en Archivo General del Estado de Campeche (en adelante AGEc), Fondo Gobernación, Sección Asuntos Religiosos, expediente 17, "Listados de Iglesias, logias y templos elaborados por los presidentes de los Municipios y dirigidos al Gobernador del Estado de Campeche”. 
A partir de las últimas décadas del siglo xıx el catolicismo mexicano emprendió una amplia labor de organización de los seglares. ${ }^{27}$ Estas iniciativas de organización vivieron un nuevo impulso bajo el régimen obregonista. ${ }^{28}$ En la diócesis de Campeche encontramos grupos de apostolado dedicados a la oración y al recogimiento, los cuales, si bien en ocasiones existían previamente, fueron ampliamente promovidos en el periodo estudiado. En junio de 1923, por ejemplo, el párroco de Palizada, Aniceto Corcuera, informó que atendía "apostolados de hombres y mujeres", y aunque no los consideraba especialmente "florecientes", creía que fortalecían el fervor y el recogimiento. ${ }^{29}$ En Calkiní el Apostolado de la Oración de Señoras y Señoritas se había fundado desde junio de 1921, y en 1923 reunía a 67 socias. También se había intentado fundar una Juventud Católica que no pudo consolidarse, pues a decir del párroco Peña "si existe, más bien se reduce a unos tres o cuatro hombres que asisten a la Santa Misa, algunos domingos, y ayudan materialmente al párroco de vez en cuando, y de aquí no pasan". ${ }^{30}$ En Hecelchakán el Apostolado había sido fundado en 1919 y en 1923 tenía 50 socias, "que cumplen con alguna regularidad". ${ }^{31}$ En todos los casos el objetivo diocesano fue impulsar los apostolados de oración para hacer de ellos centros de una incipiente formación católica. Como ha mostrado Edward Wright-Rios al estudiar el caso de Oaxaca, asociaciones como éstas buscaron moldear el catolicismo popular de los diversos grupos indígenas, de modo que en buena medida las asociaciones de fieles eran mecanismos del clero para reorientar la fe de los creyentes hacia lo que consideraban la ortodoxia católica. ${ }^{32}$ Visto así, el proceso analizado también

${ }^{27}$ Cfr. Manuel Ceballos Ramírez, El catolicismo social: un tercero en discordia. Rerum Novarum, la cuestión social y la movilización de los católicos mexicanos, 1891-1911 (México: El Colegio de México, 1991); Cecilia Adriana Bautista García, Las disyuntivas del Estado y de la Iglesia en la consolidación del orden liberal: México, 1856-1910 (México: El Colegio de México/Universidad Michoacana de San Nicolás de Hidalgo/Fideicomiso Historia de las Américas, 2012); Camacho Mercado, Frente al hambre y al obús...

${ }^{28}$ Guerra Manzo, Del fuego sagrado a la acción cívica...; Savarino, El conflicto religioso en Chihuahua...

${ }^{29}$ Carta de Aniceto Corcuera a Luis H. Maldonado, Palizada, 1 de junio de 1923, AHDC, expediente 1457, "Expedientes, cartas, cuentas y documentos".

${ }^{30}$ Carta de Miguel A. Peña a Luis H. Maldonado, Calkiní, 28 de noviembre de 1923, AHDC, expediente 1457, "Expedientes, cartas, cuentas y documentos".

${ }^{31}$ Carta de Lorenzo García Ortega a Luis H. Maldonado, Hecelchakán, 3 de enero de 1924, AHDC, expediente 1458, "Expedientes, cartas, cuentas y documentos".

${ }^{32}$ Cfr. Edward Wright-Rios, Revolutions in Mexican Catholicism. Reform and Revelation in Oaxaca, 1887-1934 (Durham: Duke University Press, 2009). 
muestra algunos elementos de renovación católica que en última instancia estaban transformando la fe de los pueblos y la relación de éstos con el clero diocesano.

En suma, el impulso a las asociaciones de laicos no fue una novedad del periodo, pero sí se buscó darle una mayor cobertura y erigirlos en centros de formación e incluso reconversión religiosa. En la década de 1920, los grupos católicos de Campeche eran asociaciones dedicadas a la oración y al culto divino, los cuales fortalecían la sociabilidad y la unión de los católicos en las distintas parroquias diocesanas. En ese sentido, las asociaciones de la oración en Campeche fueron instrumentos de organización pastoral que fomentaban la organización seglar y al mismo tiempo impulsaban la relación (local) de los fieles con la parroquia y el compromiso de éstos a través de la educación, con lo cual se impulsaban nuevos modelos de devoción. Se trató, pues, de un proyecto de renovación de la organización seglar y, en ese sentido, contribuyó a afianzar los vínculos de los católicos - ya existentes al menos desde 1910- en un contexto de pluralización de la creencia religiosa durante los años de fortalecimiento del régimen socialista de Ángel Castillo Lanz.

Hay que destacar un tercer elemento de presencia y formación católica en la diócesis: la prensa. Este factor fue directamente promovido por el obispo Francisco González Arias, y tenía como objetivo formar en las posturas católicas a los seglares y a los propios sacerdotes. En una circular emitida el 23 de junio de 1923, el obispo señaló que los párrocos debían trabajar "para que haya un número mayor de suscripciones a los periódicos católicos; que se dé valor [a] sus temas”. En esta tónica, los curas debían impulsar las suscripciones y fomentar el conocimiento de "ese ramo tan importante para la causa de la religión". 33

$\mathrm{Al}$ año siguiente se observaron los primeros frutos de esta iniciativa, como demuestra una mirada tan sólo a dos parroquias. En Hecelchakán, el párroco Lorenzo García Ortega distribuía en las misas de los domingos de agosto de 1924 "cien hojitas tituladas Eco Eucarístico", las cuales "han gustado mucho y las han leído con marcadas pruebas de interés". ${ }^{34}$ En diciembre de ese mismo año, ante el éxito de la prensa entre su feligresía se suscribió

${ }^{33}$ Circular número 6 de Francisco González Arias, obispo de Campeche, AHDC, expediente 1653, "Gobierno Eclesiástico del Obispado de Campeche. Circulares, 1922-1923".

${ }^{34}$ Carta de Lorenzo García Ortega a Luis H. Maldonado, Hecelchakán, 25 de agosto de 1924, AHDC, expediente 1458-A, "Legajo 1. Diversas cartas y documentos varios. Año de $1924 "$. 
a "la prensa católica de El Paso, Texas", y recibía cada semana "unas cien hojas del Propagandista Católico", las cuales "se distribuyen en este templo parroquial todos los domingos”, así como en Tenabó. ${ }^{35}$ En Palizada, en septiembre de 1924, Aniceto Corcuera pidió la suscripción al Boletín Eclesiástico de Yucatán y reportó que en su parroquia se leían La Cruzada Eucarística, el Mensajero del Sagrado Corazón de Jesús y Acción y Fe, además de que él promovía El Ángel del Hogar y La Hoja Suelta de la ciudad de México. La diversidad de publicaciones era admirable, pues indicó "ahora les gusta leer cosas religiosas y compradas, antes ni regaladas las leían". ${ }^{36} \mathrm{El}$ avance de las lecturas católicas no se limitaba a la cabecera parroquial: en Pich el pueblo leía El Eco Eucarístico gracias al patrocinio de 100 pesos del obispo, y empezaban a llegar otros periódicos y folletos. ${ }^{37}$

Como se puede ver, gracias a la iniciativa del mitrado y a la labor cotidiana de párrocos como García Ortega y Corcuera, entre 1923 y 1924 se impulsó la lectura de la prensa religiosa en Campeche. Como ocurrió con el caso de las asociaciones, su difusión buscó ampliar la formación de los católicos y afianzar las enseñanzas y las posturas católicas. La historiografía sugiere también que la prensa sirvió como un elemento fundamental para reorientar la creencia y, aún más, la identidad católica en la diócesis. Desde el siglo xıx, por ejemplo, la prensa jugó un papel importante para fomentar un pensamiento ultramontano que sólo reconocía al clero - y más al papa- el derecho a gobernar la Iglesia, con lo cual se fomentaban además nuevos modelos de religiosidad dirigidos por los sacerdotes y anclados en una renovada identidad católica. ${ }^{38}$ Al difundir los periódicos católicos en Campeche, el obispo y los párrocos estaban impulsando un nuevo modelo eclesial que los ponía en el centro a ellos mismos.

En conjunto, pues, desde la llegada de Francisco González Arias en 1922 encontramos una amplia labor de fortalecimiento de la presencia eclesial a través de la (re)construcción de templos, la (re)organización de

${ }^{35}$ Carta de Lorenzo García Ortega a Luis H. Maldonado, Hecelchakán, 23 de diciembre de 1924, AHDC, expediente 1458-A, "Legajo 1. Diversas cartas y documentos varios. Año de $1924 "$.

${ }^{36}$ Carta de Aniceto Corcuera a Luis H. Maldonado, Palizada, 7 de septiembre de 1924, AHDC, expediente 1458, "Expedientes, cartas, cuentas y documentos".

${ }^{37}$ Carta de Aniceto Corcuera a Luis H. Maldonado, Palizada, 15 de septiembre de 1924, AHDC, expediente 1458, "Expedientes, cartas, cuentas y documentos".

${ }^{38}$ Ignacio Martínez, "La prensa religiosa en Argentina y México como herramienta moderna de la reforma ultramontana, 1840-1870", Historia Sacra 71, n. 144 (2019): 659-668, https://doi.org/10.3989/hs.2019.047. 
las asociaciones y la difusión de la prensa. Estas medidas dieron paso a una Iglesia católica más activa en las comunidades y, en consecuencia, más presente en la esfera pública, lo cual llevó a una revitalización de la Iglesia para 1924, que se expresó como una incipiente renovación del catolicismo en la diócesis. Como corolario, estas iniciativas se acompañaron de un amplio fortalecimiento del culto y de las devociones.

Entre el culto y la consagración

Entre 1923 y 1925 se fomentó el culto local por parte de los párrocos, y gracias a las iniciativas episcopales se promovieron en Campeche dos grandes cuestiones del periodo en México: la consagraciones nacionales -al Sagrado Corazón de Jesús y al Espíritu Santo-y las oraciones por el Congreso Eucarístico Nacional, el cual se celebró en 1924 y llegó a ser uno de los momentos clave de presencia católica en el país que, a la postre, llevó al conflicto armado de $1926 .{ }^{39}$ Así, mientras el obispo González Arias impulsó las consagraciones y las oraciones por el Congreso, los párrocos insistían en las fiestas y devociones locales. En conjunto, estos elementos permitieron acrecentar la presencia pública de los católicos a través del culto religioso, fomentar nuevas devociones y asegurar la participación sacramental católica; con ello se fortalecía la vida cultual de la Iglesia en Campeche y se llevaba a una actividad devocional poco practicada hasta entonces.

En los ámbitos locales destacó la insistencia de los párrocos en bendecir imágenes, actividad ligada en ocasiones a la erección de nuevos templos, y en promover actividades devocionales como las Cuarenta Horas y los novenarios. En febrero de 1923 Miguel A. Peña bendijo “dos imágenes de bulto de la Santísima Virgen María, recientemente retocadas, y bajo los títulos de la Asunción y de la Candelaria” para la iglesia de Dzitbalché, y retocó imágenes de la virgen María y del sagrado corazón de Jesús para la

${ }^{39}$ Sobre la importancia del culto local y nacional en la década de 1920 y su importancia como factor de presencia y resistencia eclesial o antecedente del conflicto religioso, véanse Solís Nicot, "Catolicismo triunfante o crisis del catolicismo..."; y Berenise Bravo Rubio, "Cultura católica frente al Tabasco Anticlerical. El proceso de beatificación de Leonardo Castellanos y Castellanos 1919-1924", Nuevo Mundo Mundos Nuevos, acceso el 14 de agosto de 2019, https://doi.org/10.4000/nuevomundo.74446. 
parroquia de Calkiní. ${ }^{40}$ En marzo de 1923 también se bendijeron imágenes para la parroquia de Bolonchén. ${ }^{41}$ Asimismo, en Calkiní y en Hecelchakán los párrocos promovían las Cuarenta Horas. ${ }^{42}$ En Semana Santa y en las fiestas parroquiales se promovieron novenarios en poblaciones tan apartadas como los diferentes templos de la parroquia de Palizada o bien, la población de Zahccabchen, en la parroquia de Calkiní. ${ }^{43}$ Tan sólo en diciembre de 1923 en esta última parroquia se celebraron "el Novenario de la Inmaculada Concepción, Triduo en Honor de Nuestra Señora de Guadalupe, Misas de Aguinaldo, la de nochebuena" y el rosario del Niño Dios, con lo cual se dio paso a una intensa vida cultual ligada al templo y, por supuesto, al sacerdote. ${ }^{44}$

El mayor impulso, sin embargo, vino de las disposiciones episcopales. En una carta pastoral emitida el 5 de marzo de 1924, el obispo González Arias exhortó a los fieles a cumplir con las actividades de la Semana Santa y los llamó a la "confesión sacramental para la remisión de los pecados”, lo que a su vez les permitiría acceder a la comunión. El obispo hizo especial énfasis en que los padres de familia se confesaran, pues con ello "compel[e]n a los hijos al cumplimiento de los graves preceptos de la Iglesia”. ${ }^{45}$ El llamado episcopal parece haber rendido fruto: en julio de 1924 el párroco de Calkiní informó que en esos meses los fieles habían asistido a los actos

${ }^{40}$ Carta de Miguel A. Peña al obispo Francisco González, Calkiní, 5 de febrero de 1923, AHDC, expediente 1457-A, "Expedientes, cartas, cuentas y documentos"; y carta de Miguel A. Peña a Luis H. Maldonado, 1 de mayo de 1923, AHDC, expediente 1457, "Expedientes, cartas, cuentas y documentos".

${ }^{41}$ Carta de Gonzalo Ramírez N. a Luis H. Maldonado, Bolonchen-Ticul, 6 de marzo de 1923, AHDC, expediente 1457-A. "Expedientes, cartas, cuentas y documentos".

${ }^{42}$ Las Cuarenta Horas es una celebración litúrgica que consiste en adorar al Santísimo Sacramento 40 horas seguidas, mientras se recuerdan momentos de la Pasión de Cristo. Carta de Miguel A. Peña a Luis H. Maldonado, Calkiní, 24 de febrero de 1923, AHDC, expediente 1457, "Expedientes, cartas, cuentas y documentos”; y carta de Lorenzo García Ortega a Luis H. Maldonado, Hecelchakán, 27 de febrero de 1923, AHDC, expediente 1457, "Expedientes, cartas, cuentas y documentos".

${ }^{43}$ Carta de Miguel A. Peña a Higinio Maldonado, Calkiní, 30 de junio de 1923, AHDC, expediente 1457. "Expedientes, cartas, cuentas y documentos"; y carta de Aniceto Corcuera a Luis H. Maldonado, Palizada, 8 de septiembre de 1924, AHDC, expediente 1458-A, "Diversas cartas y documentos varios. Año de 1924".

${ }^{44}$ Carta de Miguel A. Peña a Higinio Maldonado, 2 de enero de 1924, AHDC, expediente 1458, "Expedientes, cartas, cuentas y documentos".

${ }^{45}$ Francisco González y Arias, Carta pastoral que el ilustrísimo y reverendísimo señor doctor don..., dirige a sus diocesanos con motivo de la cuaresma del presente año (Campeche: Imprenta de Joaquín Ongay Reyes, 1924), 6. 
religiosos "en numeroso concurso, y comulgaban con frecuencia". ${ }^{46}$ Como se puede colegir, los curas impulsaron actividades litúrgicas cotidianas y fomentaron devociones, la mayor parte marianas, para mantener activa la vida cultual de sus parroquias; al mismo tiempo, aprovecharon el llamado del obispo a los fieles, a mantener una mayor vida sacramental, para incentivar la participación activa de los seglares en el culto.

El mayor impulso, sin embargo, ocurrió gracias a la aplicación en la diócesis de medidas impulsadas en el nivel nacional. El 28 de mayo de 1923 González Arias comunicó que había sido informado desde México de la Cruzada Eucarística de los Niños, "en la cual se propone se haga la consagración de los niños al Sagrado Corazón de Jesús como preparación para el Congreso Eucarístico Nacional”. En consecuencia, el obispo pidió a sus párrocos que "prepar[aran] a los niños de la Doctrina Cristiana para su consagración", la cual se realizaría el 10 de junio. ${ }^{47}$ Según la carta de Joaquín Cardoso - director del Mensajero del Sagrado Corazón-, la consagración comenzaba a las ocho de la mañana, con los niños de escuelas y catecismos reunidos para escuchar una misa con cánticos y se permitía la comunión a los que ya estaban preparados. A las 11 se hacía la fórmula de consagración y finalmente "desfilan los niños ante un altar donde se encuentra la imagen del Corazón Divino, haciendo entrega a los acólitos de un ramito de flores, que cada uno ha llevado, para que se coloque en el altar, y mientras tanto se canta el himno ‘Jesús, Tú Reinarás'”. ${ }^{48}$

Los párrocos cumplieron el llamado del obispo y buscaron apegarse a lo señalado desde la capital de la república. ${ }^{49}$ En Ciudad del Carmen Aniceto Corcuera informó que había cumplido la circular episcopal "en toda la línea". Vale la pena recuperar su narración:

El día 10 fue un gran día de fiestas. En la primera misa se efectuó la comunión de niños y niñas y asistieron como 40 o 50, se hizo la consagración y les repartí una estampita de la virgen de Nuestra Señora de Guadalupe. A la misa mayor asistieron como 200; al final una platiquita y la presentación de flores; a medida que entregaban

${ }^{46}$ Carta de Miguel A. Peña a Luis H. Maldonado, 7 de julio de 1924, AHDC, expediente 1458, "Expedientes, cartas, cuentas y documentos".

${ }^{47}$ Circular número 5 del obispo de Campeche, 28 de mayo de 1923, AHDC, expediente 1653, "Gobierno eclesiástico del Obispado de Campeche. Circulares, 1922-1923".

${ }^{48}$ Carta de Joaquín Cardoso a Francisco González, México, 2 de abril de 1923, AHDc, expediente 1457-A, "Expedientes, cartas, cuentas y documentos".

${ }^{49}$ Carta de Lorenzo García Ortega a Luis H. Maldonado, Hecelchakán, 7 de junio de 1923, AHDC, expediente 1457, "Expedientes, cartas, cuentas y documentos. 
las flores les daba una estampita del Sagrado Corazón de Jesús, fueron 110 las estampitas que repartí en esta misa [...] El pueblo cantaba con entusiasmo el "Tú Reinarás”, hubo voladores, cañonazos y estaba la población toda conmovida. [...] En la noche hubo procesión del Sagrado Corazón con la gran imagen de lienzo de dos metros que Ud. conoce que estaba sin marco hacía como 30 años y le hicieron uno de caoba para su fiesta costeado por mí y la hermandad. ${ }^{50}$

Corcuera aprovechó la disposición del obispo para celebrar también amplias muestras públicas de devoción al Sagrado Corazón de Jesús. El 7 de junio hizo una velada con el Santísimo Sacramento expuesto y resaltó "la iglesia llena de gente con un recogimiento y fervor nunca vistos”. Al día siguiente realizó consagraciones de adultos de ambos sexos y llevó a cabo una procesión con el Santísimo en la nave del templo. Hizo notar "la devoción que hubo en esta procesión, los niños en dos filas alumbrando con sus velas, las niñas obsequiando flores y a la incensación todos animados como por una corriente eléctrica se iluminaban, cosa que antes no se usaba". ${ }^{51}$ Más allá del énfasis de Corcuera por ensalzar su labor ante el obispo, su larga descripción revela que la consagración de niños (y adultos) al Sagrado Corazón de Jesús en junio de 1923 fue promovida por el obispo y aprovechada por el clero diocesano para fomentar las prácticas devocionales de la feligresía y mostrar, a pesar de encontrarse limitados al templo, el vigor del catolicismo en Campeche. Al mismo tiempo, esas prácticas fomentaron la vinculación de los seglares con el templo y dieron paso a un nuevo modelo de devoción cada vez más cercana al templo y avalada por los sacerdotes.

Un año más tarde, el 28 de junio de 1924, el obispo de Campeche emitió una carta pastoral en la que exhortó a los fieles adultos a consagrarse al Sagrado Corazón de Jesús como un acto "deliberad[o] y con toda seriedad, y que habrá de consistir en que os ofrezcáis a trabajar con zelo [sic] y por amor al Sacratísimo Corazón de Jesús. Ofreciéndose como soldado para para luchar y sacrificarse por su causa”. Para el obispo, consagrarse al Sagrado Corazón era "hacerse Apóstoles y Aliados suyos para trabajar en más o en menos, pero en todo caso trabajar, para que Jesucristo triunfe". Entre las obras que González Arias proponía para cumplir tal labor se encontraban sumarse a alguna asociación piadosa, propagar la comunión, ser catequista

${ }^{50}$ Carta de Aniceto Corcuera a Luis H. Maldonado, Ciudad del Carmen, 20 de junio de 1923, AHDC, expediente 1457, "Expedientes, cartas, cuentas y documentos".

${ }^{51}$ Carta de Aniceto Corcuera a Luis H. Maldonado, Ciudad del Carmen, 20 de junio de 1923, AHDC, expediente 1457, "Expedientes, cartas, cuentas y documentos". 
o entronizar la imagen del Sagrado Corazón en casa. ${ }^{52}$ Como se ve, buscaba sobre todo difundir el culto público y la práctica sacramental al incentivar a los fieles a acercarse a la Iglesia, promover el contacto de los fieles con la Eucaristía y fomentar las agrupaciones católicas en la diócesis.

Un nuevo momento para exaltar la práctica devocional de los católicos en el obispado fueron los preparativos para el Congreso Eucarístico Nacional. Si bien se había pensado llevarlo a cabo en febrero de 1924, los obispos y arzobispos del país acordaron retrasar su celebración a octubre debido a la "intranquilidad política del país y la escasez de fondos”. ${ }^{53}$ La disposición permitió al obispo encargar a los clérigos del obispado que se intensificara la enseñanza catequística, se promoviera un mayor acercamiento a los sacramentos y se incentivara la devoción y el culto al Santísimo Sacramento. ${ }^{54} \mathrm{~A}$ partir de entonces y a lo largo del año el obispo impulsó la celebración de días y semanas a favor del congreso. En junio, por ejemplo, informó a sus clérigos que, siguiendo a la comisión organizadora, había declarado el 19 de junio como día del congreso, por lo que ordenó que se hicieran oraciones y comuniones, además de pedir limosnas para el evento. ${ }^{55}$ En octubre, además, se realizó una Semana Eucarística en la diócesis con el mismo objetivo. Además de la labor continua de los párrocos, destacó la presencia de los seglares, quienes participaron activamente en las festividades. A decir del cura interino Juan Rivero, en Calkiní las solemnidades "estuvieron muy concurridas y hubo comuniones de adultos, de niños perseverantes y de primera comunión”; el evento concluyó con la iluminación del templo y con una procesión externa que llevaba al Santísimo. ${ }^{56}$ En Ciudad del Carmen, el párroco Faustino Rebolledo contabilizó 4640 visitas al Santísimo y más de 7000 comuniones. ${ }^{57}$

52 Carta Pastoral a la ciudad de Campeche con motivo de la conclusión del mes de junio dedicado al Sacratísimo Corazón de Jesús, emitida por Francisco González Arias el 28 de junio de 1924, AHDC, Sección Gobierno, "Libro Quinto del Curato de Campeche, 11 de mayo de 1858 ".

${ }^{53}$ Decreto de los obispos y arzobispos de México, dado el 12 de diciembre de 1923, AHDC, expediente 1653, "Gobierno eclesiástico de Campeche. Circulares, 1922-1923”.

${ }^{54}$ Circular número 7 del obispo de Campeche, Francisco González y Arias, AHDC, expediente 1653, "Gobierno eclesiástico del obispado de Campeche. Circulares, 1922-1923”.

55 Circular número 8 del obispo de Campeche, Campeche, 30 de junio de 1924, AHDC, expediente 1653, "Gobierno eclesiástico del obispado de Campeche. Circulares, 1922-1923".

${ }^{56}$ Carta de Juan Rivero a Luis H. Maldonado, Calkiní, 12 de octubre de 1924, AHDC, expediente 1458-A, "Legajo 1. Diversas cartas y documentos varios. Año de 1924”.

${ }^{57}$ Carta de Faustino Rebolledo a Luis H. Maldonado, Ciudad del Carmen, 10 de noviembre de 1924, AHDC, expediente 1458-A, "Legajo 1. Diversas cartas y documentos varios. Año de 1924". 
El mejor ejemplo de la magnitud que tuvo la Semana Eucarística en Campeche es lo ocurrido en Palizada entre el 5 y el 12 de octubre de 1924, mientras en la ciudad de México se desarrollaba el Congreso Eucarístico Nacional. En aquella parroquia del sur de la diócesis se realizaron eventos toda la semana. Entre el 5 y el 8 de ese mes se expuso el Santísimo Sacramento, se rezó un rosario en la parroquia y el párroco dictó una plática diaria sobre la eucaristía. El 9 de octubre se efectuaron primeras comuniones, donde también participaron los niños "de la Cruzada Eucarística y de la Doctrina"; al día siguiente hubo misas solemnes para las asociaciones - socios del Apostolado, divididos por sexo y la Congregación de Nuestra Señora de Guadalupe-y el 12 se llevó a cabo "la solemne procesión del Santísimo". ${ }^{58}$ Desde la perspectiva de Aniceto Corcuera, aquellas celebraciones tuvieron "un éxito asombroso", pues fueron "un acontecimiento nunca visto en los fastos históricos de esta parroquia”. Las mujeres habían participado en las adoraciones nocturnas, y “ ¡hombres! Muchos hombres a los pies del altar en sus reclinatorios que para el caso mandé hacer". Asistieron "de todos los rincones de la parroquia, algunos desde 10 o 12 leguas [...] con gran fervor". Tan sólo en la última noche se hicieron más de 150 comuniones y, a decir del párroco, "se ha dejado sentir la mano del Señor". ${ }^{59}$

En conjunto, la consagración de los niños al Sagrado Corazón de Jesús y las iniciativas devocionales para celebrar el Congreso Eucarístico Nacional fueron una oportunidad para que el clero de Campeche profundizara su trabajo pastoral, fomentara la práctica pública de la fe e incentivara el acercamiento de los seglares a los sacramentos y, en consecuencia, a la Iglesia católica. Estas medidas ayudaron a fortalecer la fe de los fieles y permitieron mostrar el vigor y la presencia pública de la Iglesia católica en las distintas parroquias de la diócesis con elementos como comuniones, procesiones y, por supuesto, consagraciones. La importancia de estas medidas fue tal que en 1925 el obispo González Arias apoyó la iniciativa del episcopado mexicano de consagrar todo México al Espíritu Santo, lo cual se hizo en Campeche el 14 de junio de aquel año. Como había ocurrido en

${ }^{58}$ Programa de preparación para el Congreso Eucarístico Nacional en Palizada, AHDC, expediente 1458, "Expedientes, cartas, cuentas y documentos".

${ }^{59}$ Carta de Aniceto Corcuera a Luis H. Maldonado, Palizada, 12 de octubre de 1924, AHDC, expediente 1458, "Expedientes, Cartas, cuentas y documentos". 
1924, se reportó en la diócesis “una fervorosa Consagración”, que en última instancia mostraba el fortalecimiento del clero ante sus propios fieles. ${ }^{60}$

\section{Los conflictos con el poder civil}

El éxito de la presencia pública y devocional de la Iglesia católica en Campeche abrió desde 1922 varios conflictos entre el clero y los gobiernos municipales; estas pugnas concluyeron con la expulsión de la mayor parte de los sacerdotes de la entidad en 1926. De hecho, el fortalecimiento de la Iglesia durante el episcopado de Francisco González Arias dio paso a varios enfrentamientos con la autoridad civil. Algunos de los primeros roces tuvieron un carácter simbólico y surgieron como peticiones o señalamientos de las autoridades municipales y federales; su objetivo fue limitar la presencia pública del clero en la sociedad o bien enfatizar la preeminencia de la autoridad civil sobre la jerarquía eclesiástica.

El primero de ellos fue una llamada de atención al obispo por haberse "paseado" con el traje talar por las calles de Chiná. En tanto esto era una infracción a "las leyes de Reforma", el presidente municipal impuso a González Arias una multa de 200 pesos. ${ }^{61}$ El obispo rechazó el cargo, pues argumentó que no había andado por la calle vestido como clérigo, sino que al buscar al comisario municipal "para alcanzar un entendimiento en vista de ciertas dificultades que existían entre los católicos de Chiná y la [...] autoridad municipal" la sotana, que llevaba "recogida interiormente" y "bajo un saco de dril blanco que me cubría hacia afuera”, se le cayó al llegar a la casa del comisario. ${ }^{62}$ Al parecer la multa se conmutó, pero la amonestación sirvió para mostrar al obispo que se revisaría con cuidado cualquier muestra pública de culto público externo, a pesar de que en otras poblaciones podía haber incluso procesiones.

${ }^{60}$ Decreto de Francisco, obispo de Campeche, a sus párrocos, Campeche, 3 de junio de 1925, AHDC, expediente 1653, "Gobierno eclesiástico del obispado de Campeche. Circulares, 1922-1923".

${ }^{61}$ Este conflicto lo relata también May González, Conflicto religioso en...; cfr. la carta del presidente municipal de Campeche a Francisco González Arias, AHDC, expediente 1503, "Correspondencia con el Gobierno Civil, 1922-1926".

${ }^{62}$ Carta del obispo de Campeche al presidente municipal de Campeche, Campeche, 1 de septiembre de 1923, AHDC, expediente 1503, "Correspondencia con el Gobierno civil, 1922-1926". 
Un nuevo conflicto con las autoridades municipales de la ciudad episcopal surgió a partir de un pozo ubicado en el atrio de la catedral. En octubre de 1922 el alcalde de Campeche pidió permiso para conectar la tubería de la plaza de armas al tanque de la iglesia para regar las plantas del jardín central. El obispo contestó que no tenía problema en ceder el agua, pero pedía que se instalara un tanque exclusivo para ello, de modo que no se afectara su propio abasto. Se buscó un acuerdo hasta mayo de 1923, cuando González Arias señaló que no podía conceder el líquido, pues generaría escasez y, además, era “del todo imposible conciliar los intereses”. El presidente municipal recurrió entonces al administrador de la Aduana Marítima de la ciudad, quien concedió el agua al ayuntamiento "sin perjuicio del gasto" realizado por el templo. Cuando el presidente municipal insistió, en marzo de 1924, González Arias señaló al administrador de aduanas - y no al presidente municipal - que el agua estaba "ya casi agotada" y, en consecuencia, no era posible otorgarla más que a la Aduana, con lo cual se concluyó el conflicto. ${ }^{63}$

Por supuesto, esto llevó a una creciente tensión entre las autoridades diocesanas y el municipio. En enero de 1926 el vicario general, Luis Higinio Maldonado, pidió al secretario de Hacienda federal que interviniera para que no fuera demolido el atrio y el embanquetado de la catedral y del templo del Jesús, como había amenazado la presidencia municipal. El director de Bienes Nacionales dio garantías a Maldonado de que la Secretaría no lo permitiría, pues los templos - le recordó- eran bienes nacionales. ${ }^{64} \mathrm{Si}$ bien estos conflictos concluyeron sin llegar a un enfrentamiento mayor, ambas pugnas mostraron que las autoridades locales estaban dispuestas a enfrentarse al clero diocesano. Aún más: eran una muestra de cómo buena parte de los políticos del estado compartían las posturas radicales en torno a la Iglesia que propugnaba el Partido Socialista Agrario de Campeche, el cual

${ }^{63}$ Cartas del presidente municipal de Campeche al obispo de Campeche, 4 de octubre de 1922 y 22 de mayo de 1923; cartas del obispo de Campeche al presidente municipal de Campeche, 5 de octubre de 1922, 1923 (sin mes ni día) y 1 de marzo de 1924; carta del administrador de la Aduana Marítima al obispo de Campeche, 18 de mayo de 1923; y carta de Francisco González Arias al administrador de la Aduana Marítima de Campeche, Campeche, 1 de marzo de 1924, AHDC, expediente 1503, "Correspondencia con el gobierno civil, 1922$1926 "$.

${ }^{64}$ Carta de Luis H. Maldonado al secretario de Hacienda, Campeche, enero de 1925; y carta del director de Bienes Nacionales a Luis H. Maldonado, párroco del Sagrario de Campeche, 26 de enero de 1926, AHDC, expediente 1503, "Correspondencia con el Gobierno Civil, 1922-1926". 
llegó a sostener en su periódico Rojo Amanecer que era necesario combatir enérgicamente al clero. ${ }^{65}$ Esta reacción es interesante, pues muestra que el conflicto entre autoridades civiles y eclesiásticas en torno al papel de la Iglesia y aun la fe entre la sociedad se discutían ya en la década de 1920. A diferencia de lo ocurrido en el decenio siguiente, estudiado por Ben Fallaw, empero, aún no se había planteado la posibilidad de alcanzar acuerdos regionales en contra del anticlericalismo revolucionario, como de hecho se realizaron entre los políticos locales emanados de la Revolución y los católicos recalcitrantes cuando se intentó frenar la reforma educativa llegada de la ciudad de México. ${ }^{66}$

Los conflictos más arduos ocurrieron por el control de las estadísticas y por la presencia de sacerdotes españoles en la diócesis. En diciembre de 1922 el gobernador Ramón Félix Flores pidió al obispo que se enviara a las presidencias municipales la información sobre bautizos y matrimonios. ${ }^{67}$ Se pidió entonces la opinión del arzobispo de Yucatán, Martín Trischler, quien sostuvo que se podía seguir lo practicado en aquella arquidiócesis: entregar "la nota numérica" de bautizos, matrimonios y defunciones. ${ }^{68}$ Para tener una política uniforme en el obispado, el obispo González ordenó que se enviara la información mensualmente a las presidencias municipales que se especificaran sólo números y en el caso de bautismos, el sexo. ${ }^{69}$ A pesar de las disposiciones episcopales no se envió la información, de modo que en mayo de 1924, el Director General de la Oficina de Censo y Demografía notificó al obispo de Campeche - como al resto de los prelados del país- que debía enviar información sobre bautizos al gobierno civil, pues así lo dictaba el reglamento del Departamento de Estadística Nacional y porque así lo había decidido el arzobispo de México José Mora

${ }^{65}$ Cfr. Ángel Omar May González, "Propaganda e ideología en la prensa. El caso del Rojo Amanecer en Campeche, 1921-1923”, Signos Históricos, n. 27 (2012): 85.

${ }^{66}$ Como se expresó, por ejemplo, a través de la escuela y la parroquia de Calkiní. Cfr. Ben W. Fallaw, “'Anti-Priests' Versus Catholic-Socialists in 1930s Campeche: Federal Teachers, Revolutionary Communes, and Anticlericalism”, en Faith and Impiety in Revolutionary Mexico, ed. de Matthew Butler (Nueva York: Palgrave Macmillan, 2007), 216-217.

${ }^{67}$ Carta de Luis H. Maldonado al presidente municipal de Campeche, 4 de diciembre de 1922, AHDC, expediente 1503, "Correspondencia con el gobierno civil, 1922-1926".

${ }^{68}$ Carta de Martín, obispo de Yucatán, a Luis H. Maldonado, Mérida, s. f., AHDc, expediente 1503, "Correspondencia con el gobierno civil, 1922-1926".

${ }^{69}$ Circular número 2 del obispo de Campeche, Campeche, 12 de enero de 1923, AHDC, expediente 1653, “Gobierno eclesiástico del obispado de Campeche. Circulares, 1922-1923”. 
y del Río. ${ }^{70}$ Siguiendo la disposición federal, el presidente municipal de Campeche pidió a González Arias que le remitiera mensualmente los datos de matrimonios y nacimientos realizados "en templos católicos". ${ }^{71}$ Durante los meses siguientes los presidentes municipales replicaron las peticiones en el interior del estado. Para señalar sólo un caso, el alcalde de Tenabó pidió estos datos al cura de Hecelchakán, Lorenzo García Ortega, y éste pidió autorización a la diócesis, señalando que se negaría a otorgar la información hasta recibir autorización. ${ }^{72}$ Como respuesta, el obispo instruyó a sus curas a entregar la información numérica, la cual empezó a remitirse desde agosto de $1924 .^{73}$

Meses más tarde, en octubre, el presidente municipal de Campeche envió al obispo "48 boletas", de bautizos y matrimonios, para que se rellenaran con toda la información resguardada en los archivos parroquiales. Entre otros aspectos solicitaban la nacionalidad y la raza de quienes recibían los sacramentos. El 13 de noviembre el vicario general, Luis Higinio Maldonado, avisó que ya había pedido a los párrocos remitir la información estadística a las presidencias municipales, pero que no podían entregar todos los datos solicitados por el simple hecho de que no solían registrarlos. Tras el cruce de cartas en el mismo tenor entre el vicario y el alcalde, el obispo dispuso el 25 de noviembre que se llenaran las actas. Pidió a los curas llenar los formatos "según [su] buen criterio", y que apuntaran el sexo y la edad de los bautizados "con los libros a la vista". En cuanto a la raza propuso una fórmula que, desde su perspectiva, garantizaba la mayor cantidad de aciertos: "si los dos apellidos son españoles, la raza es BLANCA; si un apellido es español y el otro es indígena, la raza es INDíGENA MEZCLADA,

${ }^{70}$ Oficio del director general de la Oficina de Censo y Demografía al obispo de Campeche, México, 10 de mayo de 1924, AHDC, expediente 1503, "Correspondencia con el gobierno civil, 1922-1926".

${ }^{71}$ Carta del presidente municipal de Campeche al obispo de Campeche, Campeche, 9 de julio de 1924, AHDC, expediente 1503, "Correspondencia con el Gobierno Civil, 19221926”. Cfr. la carta del presidente municipal de Tenabó al presbítero Lorenzo García, Tenabó, 6 de junio de 1924, AHDC, expediente 1503, "Correspondencia con el gobierno civil, 1922$1926 "$.

${ }^{72}$ Carta del presidente municipal de Tenabó al presbítero Lorenzo García, Tenabó, 6 de junio de 1924, AHDC, expediente 1503, "Correspondencia con el Gobierno Civil, 1922-1926"; y carta de Lorenzo García Ortega a Luis H. Maldonado, 9 de junio de 1924, AHDC, expediente 1458, "Expedientes, cartas, cuentas y documentos".

${ }^{73}$ Hay acuses de recibo de la presidencia municipal de Campeche desde el 19 de agosto. Carta del presidente municipal de Campeche al obispo de Campeche, Campeche, 19 de agosto de 1924, AHDC, expediente 1503, "Correspondencia con el gobierno civil, 1922-1926". 
y si ambos apellidos son indígenas la raza es INDíGena PURA”. Además, ordenó que, salvo información que señalara explícitamente lo contrario, "todos son mexicanos". ${ }^{74}$

A diferencia de los conflictos anteriores, en esta ocasión la pugna entre las autoridades civiles y eclesiásticas no sólo giraba en torno a aspectos simbólicos o de acceso a recursos naturales, sino que discutía el control de la estadística. Si bien al final se alcanzó una negociación que permitió a ambas potestades tener la información, era evidente que los gobernantes civiles estaban cada vez más interesados en poseer y aun controlar aspectos que, como la información sacramental, se consideraban propios de la esfera eclesiástica.

El último conflicto surgió a propósito del clero extranjero en Campeche y ocurrió en 1925, cuando ya gobernaba el país el presidente Plutarco Elías Calles y el proceso de conciliación implementado por Álvaro Obregón había llegado a su fin. El 3 de abril de aquel año el presidente municipal de Campeche informó a Francisco González que para ejercer el sacerdocio en México era necesario ser mexicano de nacimiento y evitar "hacer reunión pública o privada ni en actos del culto o de propaganda religiosa, además de tener prohibido "hacer crítica de las leyes fundamentales del país, de las autoridades o en general del gobierno". Antes de cerrar la misiva, el presidente municipal pedía una lista del clero de la diócesis. ${ }^{75}$ El obispo se negó a darle esa información, "porque además de que el número y nacionalidad de los sacerdotes residentes en el estado es públicamente conocido [...] a mí me es altamente penoso y al mismo tiempo es tal acción muy indigna de mi persona, por la finalidad que en estos informes se persigue", que no era otro que

restring[ir] las pocas libertades que a la Iglesia, al clero y a los católicos dejaban las leyes anteriores a la Constitución de 1917, y por lo tanto en la aplicación del artículo 130 constitucional me considero como una víctima, no sólo en lo que toque directamente a los derechos de mi persona, como eclesiástico, sino que como

${ }^{74}$ Carta del presidente municipal al obispo de Campeche, Campeche, 27 de octubre de 1924; carta del vicario general al presidente municipal, Campeche, 8 de noviembre de 1924; Carta del vicario general al presidente municipal, Campeche, 13 de noviembre de 1924; y circular de Luis H. Maldonado a los curas de la diócesis, Campeche, 25 de noviembre de 1924, AHDC, expediente 1503, "Correspondencia con el gobierno civil, 1922-1926". Letras mayúsculas en el original.

${ }^{75}$ Carta del presidente municipal de Campeche al obispo de Campeche, Campeche, 3 de abril de 1925, AHDC, expediente 1503, "Correspondencia con el gobierno civil, 1922-1926". 
católico y como obispo que soy, representante por lo tanto de los intereses de la Santa Iglesia y de todos los católicos de esta diócesis, también me considero víctima en todo lo que el mencionado artículo suprima, limite o modifique desfavorablemente los derechos de la Iglesia y de los católicos de Campeche. ${ }^{76}$

El presidente municipal no envió ninguna respuesta, pero unos días después volvió a la carga: escribió a González Arias que tenía noticias de que el clérigo español Manuel Menéndez había oficiado en Campeche, y le recordaba que el ministerio de sacerdotes españoles estaba prohibido en el país. ${ }^{77}$ Pero el obispo había ya cerrado cualquier canal de comunicación: el 16 de abril de 1925 envió una amplia circular a sus párrocos.

En aquella comunicación señaló a sus clérigos que desde hacía una semana la presidencia municipal le exigía una lista de sacerdotes, y que él se había negado a otorgarla porque "la finalidad es aplicar el artículo 130". Ese mismo día, seguía, había recibido una carta donde se le amenazaba "con imponerme multa y consignarme a la autoridad federal si la presidencia municipal llega a saber que está en funciones algún ministro extranjero". En consecuencia, el mitrado advirtió a los sacerdotes que era posible "algún acto de violencia" contra ellos o contra él mismo. Para evitar cualquier ataque, liberó a los párrocos "de la obligación de oficiar públicamente, para que así quede dentro del terreno constitucional y pueda permanecer [en su curato]", y de hecho les pidió permanecer en sus parroquias. Les propuso entonces practicar "una nueva forma de apostolado": celebrar misa "en un lugar decente de su casa habitación sin admitir sino a muy reducido número de invitados", confesar también en casa a cualquier hora y bautizar ahí o en el domicilio de los interesados. Les pidió mantener el templo abierto con clases de catecismo y con la labor de las asociaciones, y aun los exhortó a "abrir una escuela con clase de religión para personas de más de

${ }^{76}$ Carta del obispo de Campeche al presidente municipal de Campeche, Campeche, abril de 1925, sin día, AHDC, expediente 1503, "Correspondencia con el Gobierno Civil, 19221926”. En el estado había siete sacerdotes mexicanos y tres españoles. Eran mexicanos el propio obispo Francisco González y los párrocos Luis H. Maldonado, del Sagrario; Francisco García Fernández, de San Francisco de Campeche; Faustino Rebolledo, de Ciudad del Carmen; Gonzalo Balmes, de Holonchenticul; Lorenzo García Ortega de Hecelchakán y Miguel A. Peña de Calkiní. Por su parte, eran españoles Manuel Menéndez R., Aniceto Corcuera de Palizada y Nicanor Múgica de Champotón. A ellos había que añadir al también ibérico Francisco Palau, de Payo Obispo, fuera de territorio campechano.

${ }^{77}$ Carta del presidente municipal de Campeche al obispo de Campeche, Campeche, 2 de mayo de 1925, AHDC, expediente 1503, "Correspondencia con el gobierno civil, 1922$1926 "$. 
quince años, para que los pueblos no resientan tanto la falta de predicación”. González Arias concluyó: "Creo en una sola palabra que dentro de la ley aún puede hacer mucho un sacerdote, portándose como tal sólo en lo particular para conservarse como he dicho dentro de los términos que no se opongan a la Constitución, y portándose en público, sobre todo en el templo como un católico fervorosísimo", y aún se dio tiempo de lamentarse: "¡Pobre México que así trata a los sacerdotes!”. ${ }^{78}$

A partir de entonces la comunicación de los párrocos con su curia se volvió cada vez más escasa. El nuevo apostolado, sin embargo, no había evitado el conflicto. En febrero de 1926 el gobierno de Campeche reglamentó el artículo 130 constitucional y permitió sólo cinco sacerdotes en el estado. En los primeros meses de 1926 los sacerdotes empezaron a dejar la diócesis: el 24 de febrero salió Nicanor Múgica, quien recibió licencia indefinida del obispo para pasar a cualquier diócesis extranjera, "en atención a que las leyes mexicanas prohíben el ministerio a los sacerdotes que no sean mexicanos por nacimiento, al mismo tiempo que las del estado de Campeche limitan a cinco el número de ministros". ${ }^{79}$ En mayo salió el cura de Bécal Manuel Menéndez, y el primero de abril Faustino Rebolledo recibió permiso de "pasar a la Arquidiócesis de México o a la de Zamora". En octubre de 1926 se permitió al cura de Payo Obispo, Francisco Palau, abandonar la diócesis, y en octubre de 1926 se apuntó que el obispo "tuvo que marchar al destierro". ${ }^{80}$ El proyecto de renovación pastoral emprendido desde la llegada de González Arias a Campeche en agosto de 1922 y la búsqueda de un nuevo apostolado habían llegado a su fin.

\section{Conclusiones}

Entre 1922 y 1925 el obispo Francisco González Arias y el clero diocesano de Campeche impulsaron la renovación y el fortalecimiento del catolicismo en aquel obispado, mediante la promoción de una presencia material,

78 Circular de Francisco, obispo de Campeche, a sus párrocos, Campeche, 16 de abril de 1925, AHDC, expediente 1653, "Gobierno eclesiástico del obispado de Campeche. Circulares, 1922-1923".

${ }^{79}$ Registro del 24 de febrero de 1926, AHDc, expediente 1654, libro número 3 de Providencias y Licencias diversas, comenzando en enero de 1923.

${ }^{80}$ Registros del 9 de mayo, 1 de abril y 26 de octubre de 1926, AHDC, expediente 1654, Libro número 3 de Providencias y Licencias diversas, comenzando en enero de 1923. 
organizativa y cultual de la Iglesia y del propio clero que no se había experimentado en la diócesis desde su fundación en 1895. A través de la (re)construcción de templos, la (re)organización de las asociaciones seglares, la promoción de la prensa católica y de una amplia práctica cultual apoyada en ocasiones en iniciativas nacionales como el Congreso Eucarístico Nacional, la jerarquía eclesiástica de Campeche desarrolló una pastoral pública que enfatizaba la autoridad y la presencia de la Iglesia católica y del clero en la ciudad episcopal y en las parroquias de la diócesis. Detrás de estas iniciativas estaba el interés de la jerarquía por fortalecer su presencia y fomentar un nuevo modelo de catolicismo, con una nueva identidad y vigilado incluso en sus aspectos cultuales por el clero. Estas iniciativas diocesanas no estuvieron exentas de disputas con las autoridades civiles: a lo largo del periodo analizado se vivieron varios conflictos con los ayuntamientos, los cuales llevaron el enfrentamiento entre ambas potestades a una creciente polarización que concluyó con el exilio de una buena parte del clero diocesano en 1926.

El interés de la jerarquía eclesiástica por ampliar la presencia de la Iglesia en Campeche se vio afectado por varios factores. En términos generales, el amplio desarrollo de las construcciones materiales y el vigor del culto católico hasta 1924 se explican por el clima de conciliación y pragmatismo del régimen de Álvaro Obregón, así como por la permisividad del régimen estatal moderado del socialista Ramón Félix Flores. Del mismo modo, el enfrentamiento con las autoridades civiles y el exilio del clero a partir de aquel año se debió en parte al fortalecimiento del régimen estatal de Ángel Castillo Lanz y a las medidas adoptadas por la presidencia de Plutarco Elías Calles. A ello hay que sumar las características de aquella Iglesia: durante el periodo se vivió un fortalecimiento de estructuras diocesanas históricamente débiles, se amplió la presencia simbólica del clero en villas y pueblos que carecían incluso de templos, se organizó y atendió a los seglares en niveles no desarrollados hasta entonces. A través de estas medidas se creó un incipiente modelo de labor eclesial que no se había presentado en Campeche hasta entonces. Algunos elementos que lo hicieron posible, sin embargo, fueron clave para su rápido desmantelamiento ante el conflicto religioso. Uno de ellos, la presencia de clérigos de nacionalidad española, vale la pena ponderarlo en el desarrollo del conflicto entre Iglesia y Estado que se vivió a partir de 1925 a propósito de temas como la estadística sacramental y la presencia de sacerdotes extranjeros. El exilio del clero - español, pero también mexicano- en 1926 responde, en buena medida, a estos elementos regionales. 
Como en otros puntos del país, el éxito de los mecanismos y estrategias diocesanos de fortalecimiento eclesial llevó al fin de la experiencia católica en la diócesis de Campeche. Desde esta perspectiva, el enfrentamiento entre autoridades civiles y religiosas en 1926 responde no sólo al anticlericalismo de los gobiernos regionales o a la voluntad de los presidentes municipales de fortalecer su autoridad - factores que por supuesto existieron-, sino a la renovada presencia de la Iglesia, el clero y los católicos en las sociedades locales. Por otra parte, Campeche permite mostrar que, como ocurrió en Chihuahua o en Oaxaca, la postura del obispo y del propio clero diocesano fue fundamental para delinear el conflicto a lo largo de la década. Francisco González Arias propuso en 1925 "una nueva forma de apostolado" que, en resumidas cuentas, apelaba a apartarse del culto público y a practicar el sacerdocio en el ámbito privado. Si bien este recurso no pudo sostenerse y el experimento diocesano emprendido en 1922 concluyó en Campeche con la salida del propio mitrado en 1926, su postura permite mostrar las distintas soluciones que la jerarquía y el clero diocesano aplicaron en la complicada década de 1920.

\section{Fuentes}

Archivos

Archivo Histórico Diocesano de Campeche (AHDC).

Archivo General del Estado de Campeche (AGEC).

Fuentes impresas

González y Arias, Francisco. Carta pastoral que el ilustrísimo y reverendísimo señor doctor don..., dirige a sus diocesanos con motivo de la cuaresma del presente año. Campeche: Imprenta de Joaquín Ongay Reyes, 1924.

Bibliografía

Abud Flores, José A. Después de la Revolución: los caciques y el nuevo Estado (Campeche, 1923-1943). México: Universidad Autónoma Metropolitana, 2012.

Aguirre Cristiani, María Gabriela. ¿Una historia compartida? Revolución mexicana y catolicismo social, 1914-1924. México: Instituto Mexicano de Doctrina Social 
Cristiana/Instituto Tecnológico Autónomo de México/Universidad Autónoma Metropolitana, 2008.

Andes, Stephen J. C. The Vatican and Catholic Activism in Mexico and Chile. The Politics of Transnational Catholicism, 1920-1940. Oxford: Oxford University Press, 2014.

Bautista García, Cecilia Adriana. Las disyuntivas del Estado y de la Iglesia en la consolidación del orden liberal: México, 1856-1910. México: El Colegio de México/ Universidad Michoacana de San Nicolás de Hidalgo/Fideicomiso Historia de las Américas, 2012.

Bravo Rubio, Berenise, "Cultura católica frente al Tabasco Anticlerical. El proceso de beatificación de Leonardo Castellanos y Castellanos 1919-1924." Nuevo Mundo Mundos Nuevos. Acceso el 14 de agosto de 2019. https://doi.org/10.4000/ nuevomundo.74446.

Bravo Ugarte, José. Diócesis y obispos de la Iglesia mexicana, 1519-1965. México: Jus, 1965. Butler, Matthew. Devoción y disidencia: religión popular, identidad política y rebelión cristera en Michoacán, 1927-1929. Zamora: El Colegio de Michoacán/Fideicomiso Felipe Teixidor y Monserrat Alfau de Teixidor, 2013.

Camacho Mercado, Eduardo. Frente al hambre y al obús: Iglesia y feligresía de Totatiche y el Cañón de Bolaños, 1876-1926. Guadalajara: Departamento de Estudios Históricos de la Arquidiócesis de Guadalajara/Universidad de Guadalajara, Centro Universitario de los Lagos, 2014.

Ceballos Ramírez, Manuel. El catolicismo social: un tercero en discordia. Rerum Novarum, la cuestión social y la movilización de los católicos mexicanos, 1891-1911. México: El Colegio de México, 1991.

Dávila Garibi, José Ignacio. "Serie cronológico-biográfica de los ilustrísimos mitrados mexicanos consagrados durante un siglo, de marzo 6 de 1831 a marzo 6 de 1931 (5a. y última parte)." En Boletín Eclesiástico. Órgano Oficial de la Arquidiócesis de Guadalajara, 42-64. Guadalajara: Arquidiócesis de Guadalajara, año 7, n. 5 (2014).

Fallaw, Ben W. “'Anti-Priests' Versus Catholic-Socialists in 1930s Campeche: Federal Teachers, Revolutionary Communes, and Anticlericalism." En Faith and Impiety in Revolutionary Mexico, edición de Matthew Butler, 203-223. Nueva York: Palgrave Macmillan, 2007.

García Ugarte, María Eugenia. "Etapa de intransigencias: disputa por el espacio social.” En Estado, Iglesia y sociedad en México. Siglo XIX, coordinación de Álvaro Matute, 399-425. México: Universidad Nacional Autónoma de México/ Miguel Ángel Porrúa, 1995.

Giuseppe, Massimo de. Messico 1900-1930. Stato, Chiesa e popoli indigeni. Brescia: Morcelliana, 2007. 
González Morfín, Juan. La guerra de los cristeros. Hitos y mitos. Los Mochis: Panorama, 2017.

Guerra Manzo, Enrique. Del fuego sagrado a la acción cívica: los católicos frente al Estado en Michoacán (1920-1940). Zamora: El Colegio de Michoacán/Universidad Autónoma Metropolitana/Ítaca, 2015.

Hernández Madrid, Miguel, ed. Documentos de pastoral cívica y social de la Iglesia católica en la diócesis de Zamora, Michoacán, 1930-1970. Zamora: El Colegio de Michoacán, 2014.

Lisbona Guillén, Miguel. "Iglesia católica y Estado en la posrevolución chiapaneca. Desencuentros y conflictos, 1917-1940.” En México católico. Proyectos y trayectorias eclesiales en México. Siglos XIX y XX, coordinación de Marta Eugenia García Ugarte, Pablo Serrano Álvarez y Matthew Butler, 396-424. Pachuca: Universidad Intercultural del Estado de Hidalgo/El Colegio del Estado de Hidalgo/ Consejo Estatal para la Cultura y las Artes de Hidalgo, 2016.

Lisbona Guillén, Miguel. Persecución religiosa en Chiapas (1910-1940): Iglesia, Estado y feligresía en el periodo revolucionario. México: Universidad Nacional Autónoma de México, Instituto de Investigaciones Antropológicas, Programa de Investigaciones Multidisciplinarias sobre Mesoamérica y el Sureste, 2008.

Martínez, Ignacio. "La prensa religiosa en Argentina y México como herramienta moderna de la reforma ultramontana, 1840-1870.” Historia Sacra 71, n. 144 (2019): 659-668. https://doi.org/10.3989/hs.2019.047.

Martínez Assad, Carlos. El laboratorio de la revolución: el Tabasco garridista. México: Siglo XXI, 1970.

May González, Ángel Omar. Conflicto religioso en Campeche, 1925-1929. Campeche: Gobierno del Estado de Campeche, PACмyc, 2007.

May González, Ángel Omar. Los primeros años de la posrevolución en Campeche (19211929). México: Instituto de Investigaciones Dr. José María Luis Mora, 2013.

May González, Ángel Omar. "Propaganda e ideología en la prensa. El caso del Rojo Amanecer en Campeche, 1921-1923.” Signos Históricos, n. 27 (2012): 64-102.

Meyer, Jean. La Cristiada. 3 v. México: Siglo XXI, 2006.

Meyer, Jean. El conflicto religioso en Oaxaca, 1926-1929. México: Centro de Investigación y Docencia Económicas, Documentos de Trabajo, 2005.

Osorio Díaz, Luis A. Tesoros de un archivo. Archivo Histórico de la Diócesis de Campeche. San Francisco de Campeche: Gobierno del Estado de Campeche, 2015.

Paoli, Francisco J. y Enrique Montalvo. El socialismo olvidado de Yucatán. México: Siglo XXI, 1977.

Romero de Solís, José Miguel. El aguijón del espíritu: historia contemporánea de la Iglesia en México, 1892-1992. México: Instituto Mexicano de Doctrina Social 
Cristiana/El Colegio de Michoacán/Archivo Histórico del Municipio de Colima/Universidad de Colima, 2006.

Rosado Cel, Armando José. Francisco Plancarte y Navarrete. El obispo arqueólogo. Campeche: Archivo Histórico de la Diócesis de Campeche, 2016.

Rugeley, Terry. De milagros y sabios: religión y culturas populares en el sureste de México, 1800-1876. Mérida: Ediciones de la Universidad Autónoma de Yucatán, 2012.

Savarino, Franco. El conflicto religioso en Chihuahua 1918-1937. Chihuahua: El Colegio de Chihuahua/Universidad Autónoma de Ciudad Juárez, 2018.

Savarino, Franco. "La Iglesia católica y el Estado durante la Revolución. Yucatán, 19101923.” En México católico. Proyectos y trayectorias eclesiales en México. Siglos XIX y XX, coordinación de Marta Eugenia García Ugarte, Pablo Serrano Álvarez y Matthew Butler, 364-395. Pachuca: Universidad Intercultural del Estado de Hidalgo/El Colegio del Estado de Hidalgo/Consejo Estatal para la Cultura y las Artes de Hidalgo, 2016.

Savarino, Franco. Pueblos y nacionalismo: del régimen oligárquico a la sociedad de masas en Yucatán, 1894-1925. México: Instituto Nacional de Estudios Históricos de la Revolución Mexicana, 1997.

Solís Nicot, Yves Bernardo Roger. "Catolicismo triunfante o crisis del catolicismo social y político: el Congreso Eucarístico de 1924." En Política y religión en la ciudad de México, siglos XIX y XX, coordinación de Franco Savarino, Berenise Bravo Rubio y Andrea Mutolo, 301-321. México: Instituto Mexicano de Doctrina Social Cristiana, 2018.

Valvo, Paolo. Pio XI e la Cristiada. Fede, guerra e diplomazia in Messico (1926-1929). Brescia: Morcelliana, 2016.

Wright-Rios, Edward. Revolutions in Mexican Catholicism. Reform and Revelation in Oaxaca, 1887-1934. Durham: Duke University Press, 2009.

\section{SOBRE EL AUTOR}

Doctor en Ciencias Humanas por el Centro de Estudios de las Tradiciones de El Colegio de Michoacán. Profesor-investigador de tiempo completo titular "A" de la BUAP. Miembro del Sistema Nacional de Investigadores. Sus líneas de investigación son Iglesia, Estado y sociedad en México y Latinoamérica, siglos XIX y xx, y usos sociales de los recursos naturales en el oriente de México, siglos xix y xx. Su más reciente libro es Miguel Negrete. Guerra y política en el México liberal (1824-1897) (BUAP/Ediciones del Lirio, 2017). 
